\title{
Modernization and Automation in Ginning and Pressing Industries for Performance Enhancement
}

\author{
Dr. S. K. Patil \\ Associate Professor \\ College of Engg. \& Technology, Babhulgaon, Akola.
}

(M.S.)India-444104.

\begin{abstract}
Looking towards the importance of improved contamination free of ginned cotton and high degree of reliability in performance of machineries in ginning setup, modernization and automation in ginning and pressing industries is required. The author has discussed the machinery set up for modernized ginning plant as well as sophisticated mechanical, electromechanical, pneumatic, hydraulic and electronic systems required for automation. The achievements observed due to Modernized and automated ginning and pressing unit are higher efficiency, improved contamination free quality of ginned cotton and high degree of reliability with reduction in cost of processing and increased productivity.
\end{abstract}

Key words: Ginning and pressing, ginned cotton, modernization.

\subsection{INTRODUCTION}

Cotton is one of the principle commercial crops in India. India ranks first in the world in area under cotton cultivation (91.58 lakh hectors); while in production as per the ranking stands second at 270 lack bales (i.e.170 kg each). In fact the average yield of cotton in India is $550 \mathrm{~kg} / \mathrm{ha}$ which is very nearer to current productivity of world average cotton production/ha. Cotton plays a vital role in Indian textile industry and accounts for about 58 percent of total fiber consumption. In spite of gigantic force of scientific community we could not meet increasing present demand of cotton from domestic and export market.

Therefore textile industries in India are resorting to import largely due to this melody. The primary objective of a commercial ginning is to separate cotton fiber from the cottonseeds. Trash in cotton refers to the content like bark, stick, leaf, pepper trash, grass, hulls and motes during picking of cotton from the field. During harvesting, pieces of leaf and other trash are picked along with the seedcotton. So the process of seedcotton cleaning and extraction machinery to extract large trash object is needed. The ginning machineries separates the lint from the seeds and material left behind in the lint can consist of bark, stick, leaf, pepper trash, grass, hulls, seed coat fragments and motes. Quality of cotton after ginning depends on the quality of harvested cotton as well as the type and the amount of cleaning performed. It is a need of time to modernize and automate ginning and pressing units to control each and every activity to get desired ginned cotton quality, increased productivity and reliability of unit. The author has discussed the machinery set up for modernized plant as well as the systems used for automation like electromechanical, pneumatic, hydraulic and electronic systems such as sensors, transducers and programmable logic controller. The feedback systems are provided to take care of processes and safety interlocks to avoid bottlenecking and breakdown in the machineries.

\subsection{TRADITIONAL GINNING AND PRESSING PROCESS}

i. Raw cotton also referred as seedcotton stored in heap in outside yard is conveyed manually to traditional cleaning machine from where it is conveyed to gin hall.

ii. Raw seedcotton is then manually fed to number of ginning machines. There are chances of running the machines idle if labor fails in giving timely supply of seedcotton to machines hence under utilization of facility. Here lint is separated from cottonseed.

iii. Ginned cotton lint is conveyed manually to storage hall. This operation is labor dependent and there are chances of contamination of foreign elements. There is a need of maintaining proper moisture content in cotton but lack of proper arrangement of maintaining moisture level in cotton.

iv. Cotton seed, which is separated by ginning machines, is conveyed to platform outside gin hall by screw conveyors and bucket elevator.

v. Lint from storage house is conveyed to press house through traditional cleaning machine where the cotton lint is compacted into bales. The process set up is shown in fig.1.

\subsection{Modernized Ginning and Pressing Process}

The entire process is continuous process and the flow of cotton through the machinery is predetermined. The ginning machine is the heart of the ginning system where fibers are separated from seeds. The remainder equipment used is for conveying especially pneumatic conveying is preferred, humidifier and extraction of trash object. The steps in modern ginning shown in Fig.2 \& Fig.4 are as under-

i. Seedcotton as well as lint cotton is conveyed pneumatically at various stages with the help of duct network in the storage yard, gin hall and press house 
connected to their respective set of condenser box, blower and cyclone. The powerful blower suction is responsible for conveying the cotton through duct while condenser box separates cotton from stream of air and lastly the dust and other light impurities are settled in cyclone. The seedcotton from outside yard is conveyed to ball trap (pre-cleaner) that removes all heavy foreign material (stones and dirt, etc) and prevent damage to other equipment while processing. It also removes unopened green cotton balls thereby preventing contamination of immature fiber with ball containing immature cotton. The inclined cleaners remove small trash particles. Their cleaning is generally low. However, one of their most important functions is to break up large clump of raw cotton and to remove any fine dust and small leaf and stick particles in seed cotton. Results have shown that the total trash removal efficiency of a six-cylinder inclined cleaner with grid rods generally ranging from 50-55 percent. Then next stage of processing is stick-cleaning

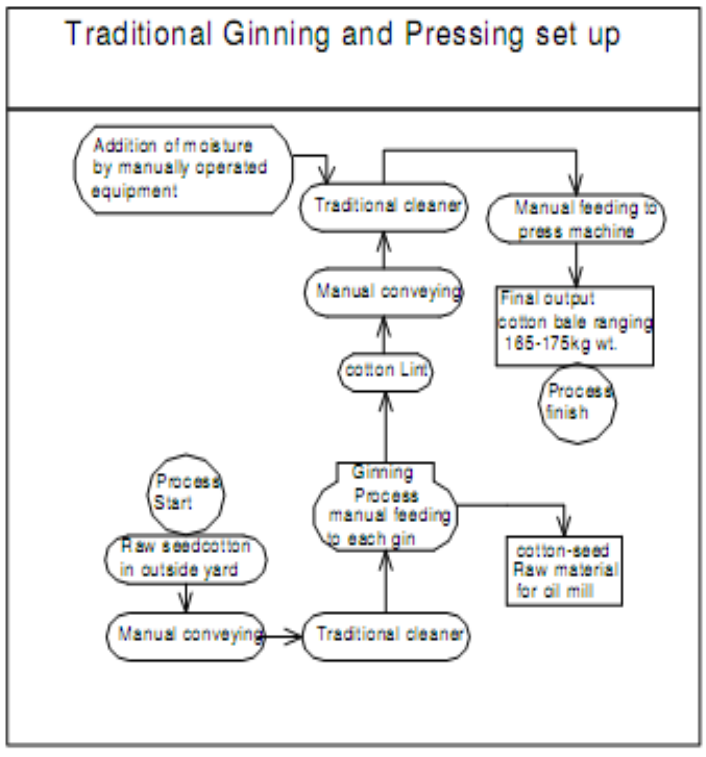

Fig.1

The moisturizing system provided is controlled manually. iv. Ginned cotton from storage hall is conveyed by pneumatic conveying system to press hall for making compacted cotton mass called cotton bale of $165-175 \mathrm{~kg}$. each on hydraulic press. The cotton is fed manually to press hence quantity of cotton per bale varies between 165 to $175 \mathrm{~kg}$.

Even in the machinery set up of modernized ginning and pressing unit discussed above have many limitations as discussed below. These limitations are overcome by implementing automation.

i. This system does not allow the judicious selection of trash cleaning machines to be included in the proceeding sequence. Combination of cleaners to be selected depends on trash contamination level and its type in seedcotton. There is no provision of measuring online contamination level in cotton. This results in seedcotton with higher stick content, entering into gin resulting in large quantities of bark in the ginned lint. machine for removal of large trash and stick removal. It is expected to remove 65 percent of burs, 50 percent of sticks, and 10-25 percent of fine trash (dust and some paper trash). Sometimes it is customary to pass through additional inclined cleaner and may be a second stick machine.

ii. Seedcotton by pneumatic conveying is now conveyed to gin hall platform. In India majority of ginning and pressing unit have standard set up of 18- 24 ginning machines installed in two rows in ginning hall. Manually seedcotton is loaded to feeder of each gin. The feeders provided feed cotton to gin uniformly in controlled rate.

iii. Ginned cotton after ginning is conveyed to lint cleaners. Lint cleaners remove the bulk of bark and leaf object present in ginned lint. The no. of stages of cleaning depends on contamination. After cleaning cotton lint is conveyed to storage hall by pneumatic conveying system. If required the desired amount of moisture is added to cotton.

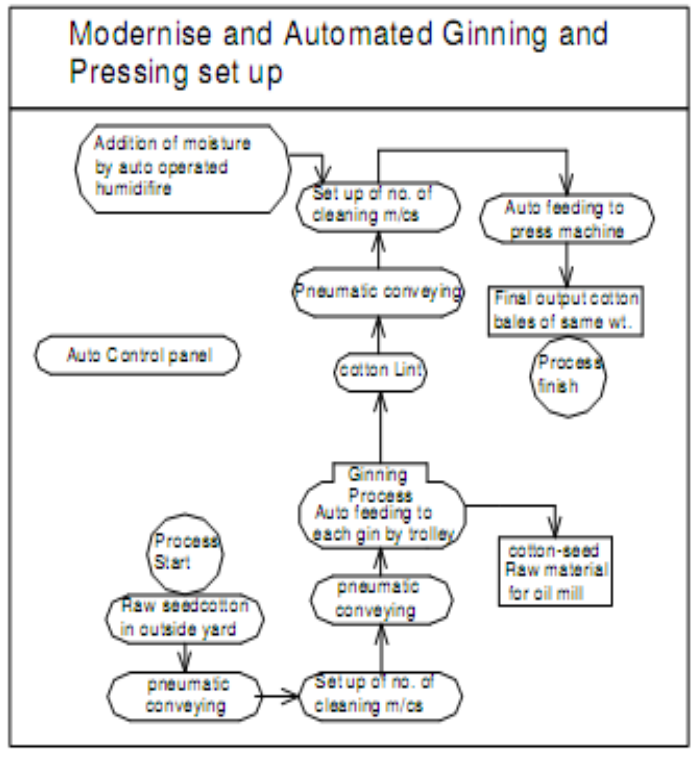

Fig.2

ii. The cottonseed is fed manually to each gin. Due to irregular feeding sometimes gin may run empty this leads to under utilization of gin capacity.

iii. Improper moisture control in cotton due to lack of auto controlled moisturizing system.

iv This system don't have online facility of getting the information of quantity of cotton at various stages in the process of ginning which is useful in judging the efficiency of machineries.

v. There are many sequential and parallel activities that need to be carried out to perform uninterrupted process. Manually it becomes tedious job and any mistake may result in to loss of production and deterioration of quality.

vi. Due to manual loading of cotton to press the bales sizes are varying. 


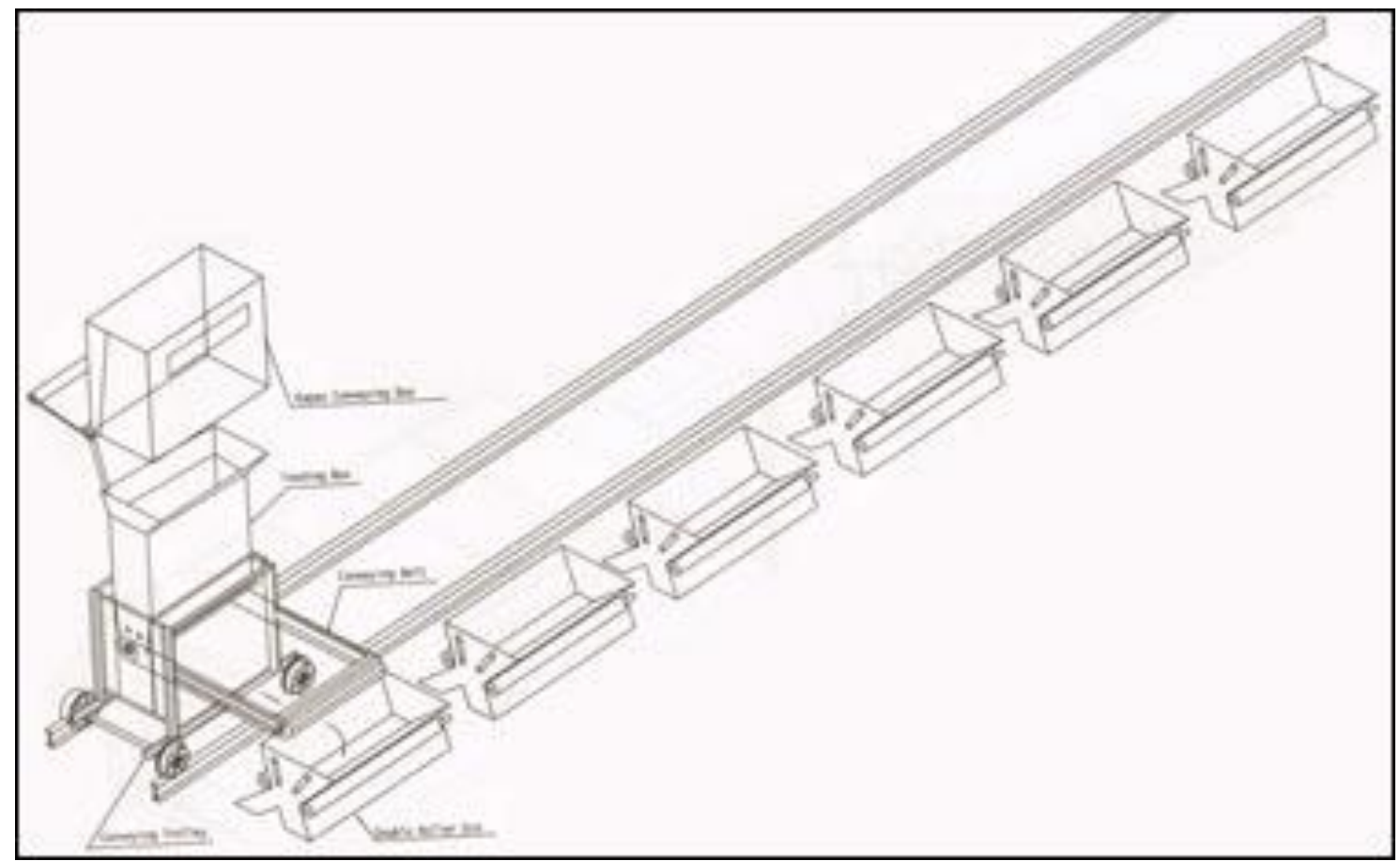

Fig .3

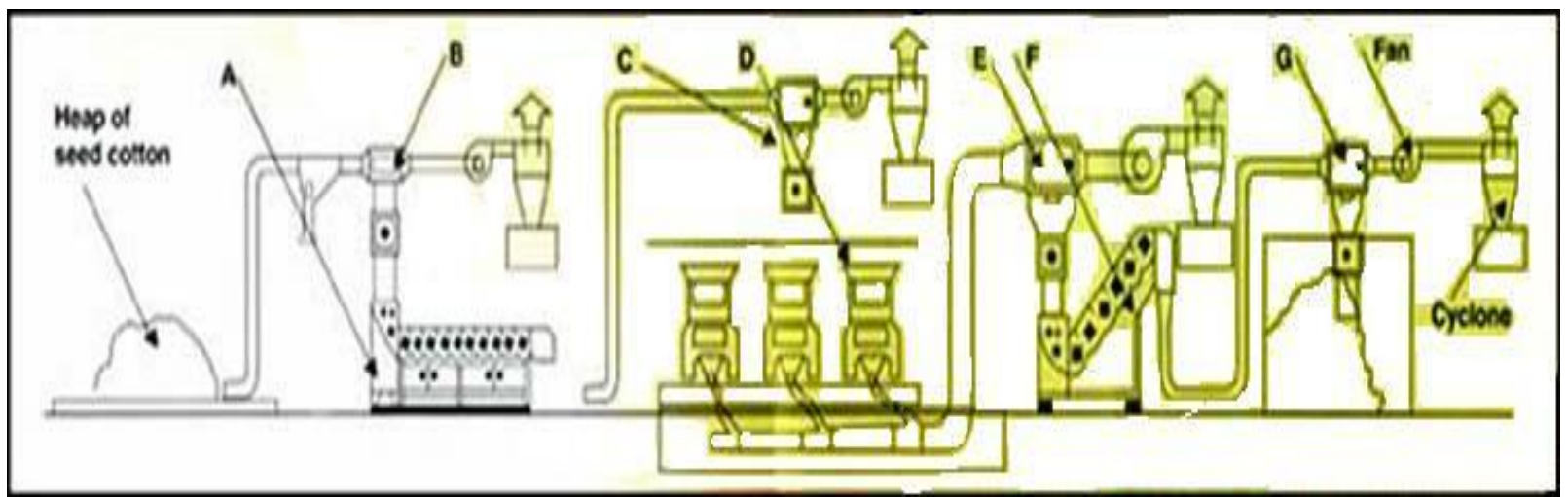

Process schematic diagram

Fig .4

A -Pre-ginning cleaning machine for hybrid seed-cotton.

B- Pneumatic seed-cotton conveying system from heap of kapas to pre-ginning cleaning machine.

C -Pneumatic seed cotton conveying system pre-ginning to centre platform.

D -Double roller gin with seed-cotton auto feeder.

E- Pneumatic cotton lint conveying system from double roller gins to post-ginning cleaning machine.

F -Post-ginning cleaning machine.

G- Pneumatic cotton lint conveying system from post-ginning cleaning machine to cotton lint hall. Cotton heap. 


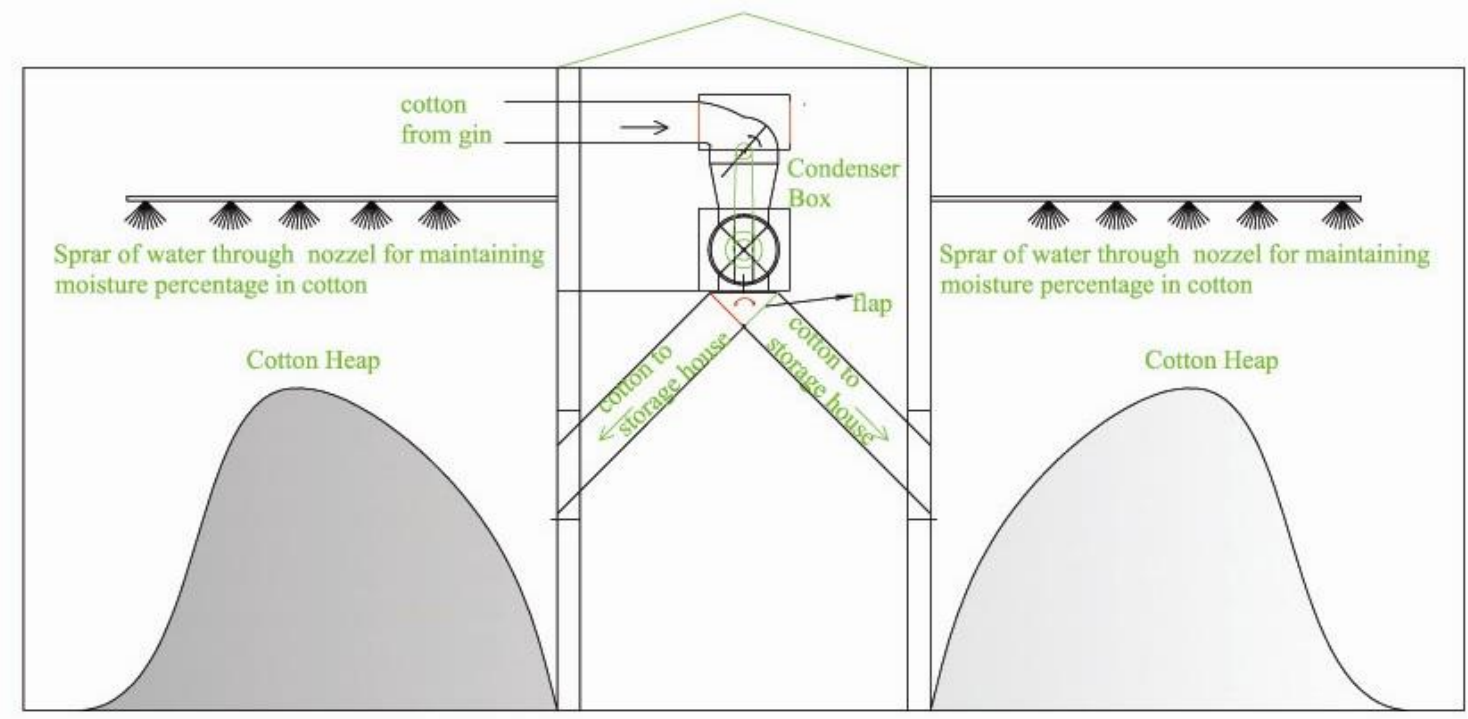

Fig .5

\subsection{SYSTEMS USED FOR AUTOMATION}

i. Trash meter and camera vision system -It has to be installed at the entry of pre cleaning machines in raw cotton and also after ginning to know contamination level in cotton before precleaning and after ginning. The data is provided to programmable logic controller (PLC). PLC takes judicious decision regarding selection of required cleaning machines and bypassing unwanted cleaning machines.

ii. Provision of online load cell mounted weighing arrangement to know weight of cotton at various stages in process was made as mentioned below.

a) Cotton entering in first cleaner. b) Cotton entering in gin hall. c) Lint entering in storage hall. d) Cotton lint entering in cleaning machine after ginning. e) Cotton to be loaded in press. f) Cottonseed after ginning.

iii. The auto feeding trolley installed to feed cotton to each gin $\mathrm{m} / \mathrm{c}$ in gin hall(see fig3). The infrared sensors are mounted in feeder hopper of gin to know cotton level. The signal is given to PLC. Trolley runs on overhead rails. Proximity sensors give the signal of location of particular gin and the cotton is fed to gin with the help of belt conveyor provided in trolley. When the desired level in feeder of gin is sensed by infrared sensor the signal is given to PLC. Trolley stops feeding and goes to next empty gin. There is normally a standard set up of 18-24 gins arranged in two rows and the provisions of two trolleys were made to take care of two rows. Trolley gets cotton from condenser box provided in pneumatic conveying system. In trolley hopper there is a provision of cotton level sensing infrared sensor. As and when required the trolley runs to weighing hopper mounted beneath the condenser box. Trolley gets weighed quantity of cotton. This gives information of input cotton to gin machines.

iv. Selector valves and bypass valves- Pneumatic cylinders are mounted to operate all the valves. Selector valves are located in the pneumatic conveying duct network. These valves select the suction points as well as dropping points for cotton at various stages. Normally there are four number of storage houses. The selector valves select the empty house for loading ginned cotton being conveyed pneumatically. All these activities are controlled by PLC.

v. Moisture meter and humidifying system- The moisture content in the cotton in storage house is checked by moisture meter on line of the sample given by flow sampler provided to take samples periodically. As per the signal of moisture meter the desired moisture is added to the cotton in storage hall. (see fig.5)

vi. Auto operated fire fighting system- Fire hazard is more in case of cotton. There is an urgent need to have auto fire fighting system. The spraying system installed has provision of quartzite bulb. In case of fire the temperature rises and the bulb breaks giving signal to controller and the system starts automatically.

vii. Programmable logic controller -Automatic control unit is a programmable logic controller (PLC) with $100 \%$ optically isolated interface to the actuator and limit switches, sensors. The PLC is powered with inbuilt switching mode. Powder supply (SMPS) with adequate transient and fine filtering. The solenoid and actuators are driven by solid-state switches long life and better reliability. The motor control contactors (MCC) and overload relay are housed in same control panel supported by backup fuses. Central processing unit performs the operations like continuous check and display the status of each activity of plant, Controlling and monitoring of conveying system, timely feeding of desired quantity of cotton to each gin, controlling moisture of cotton in storage house and judicious selection of cleaning machines on the basis of contamination level. Control panel contains all the power equipment as circuit breakers, fuses, motor starters, thermal overload relays etc. Automation panel is provided with Auto and manual functions as below, 
Auto Mode: - Automatic functioning and controlling by CPU.

Manual Mode: - Manual functioning controlled but not adjusted by CPU.

The option of manual mode is used while checking or maintenance of various units.

\section{0 RESULT AND DISCUSSION}

The comparative data presented in table.no. 1 revealed that operating cost saved by modernized automated unit is Rs.69.5/bale. The labor required reduced up to $90 \%$. Table. 1 also reveals that the extra ginning \& pressing cost gained in job work with modernized automated ginning and pressing unit is Rs20,96,500/season. Modernization and automation of ginning \& pressing resulted in increased demand in local and export market due to quality output. Quality of ginned cotton from modernization and automation of ginning and pressing unit fetches good price as well as attracts local and export market. No need of skilled operator as settings is performed automatically for uninterrupted and smooth functioning of total unit. Indian Govt. is promoting modernized plant by giving financial assistance.

Table 1. Quantitative benefits of Modernized automated Ginning and Pressing unit

(Considered season of 120 working days)

\begin{tabular}{|c|c|c|c|c|}
\hline \multicolumn{2}{|c|}{ Particular } & $\begin{array}{l}\text { Modernized automated } \\
\text { unit with } 18 \text { Gins set up. }\end{array}$ & $\begin{array}{l}\text { Traditional unit } \\
\text { with } 18 \text { Gins set up. }\end{array}$ & Cost comparison \\
\hline \multirow[t]{6}{*}{ Power } & Ginning & $18 \times 5=90 \mathrm{hp}=67.5 \mathrm{kw}$ & $18 \times 5=90 \mathrm{hp}=67.5 \mathrm{kw}$ & \multirow{6}{*}{$\begin{array}{l}\text { Extra power cost } \\
\text { in modernize } \\
\text { gin/season= } \\
\text { Rs. } 16,84,800 /- \\
(97.5 \mathrm{kwx} 24 \mathrm{hrx} 12 \\
\text { OdaysxRs.6/kw) }\end{array}$} \\
\hline & Conveying & $105 \mathrm{hp}=78.75 \mathrm{kw}$ & Nil & \\
\hline & Cleaners & $21 \mathrm{hp}=15.75 \mathrm{kw}$ & $6 \mathrm{hp}=4.5 \mathrm{kw}$ & \\
\hline & Compressor & $10 \mathrm{hp}=7.5 \mathrm{kw}$ & Nil & \\
\hline & Press $\mathrm{m} / \mathrm{c}$ & 57 H.P. $=42.75 \mathrm{kw}$ & 57 H.P. $=42.75 \mathrm{kw}$ & \\
\hline & Total Power & 212.25kw/h@Rs.6/kw & 114.7 kw/h@Rs.6/kw & \\
\hline \multicolumn{2}{|c|}{ Labour } & $\begin{array}{l}6 \text { labor/shift of } 8 \text { hr } \\
\text { (a) Rs.150/labour/shift }\end{array}$ & $\begin{array}{l}\text { 581abor/shift of } 8 \mathrm{hr} \\
\text { @ Rs.150/labour/shift }\end{array}$ & $\begin{array}{l}\text { Extra labor cost } \\
\text { in traditional unit } \\
=28,08,000 /- \\
\text { 52laborx3shiftx1 } \\
\text { 20daysxRs.150) }\end{array}$ \\
\hline \multicolumn{2}{|c|}{$\begin{array}{l}\text { Operating cost saved by } \\
\text { Modernized automated } \\
\text { unit (Power \& labour cost } \\
\text { saved/ season) }\end{array}$} & $\begin{array}{l}\text { Rs.39,91,680/season } \\
\text { Rs.174.53/bale } \\
\text { (Power } \\
\text { cost }=36,67,680 / \text { season } \\
\text { And Labor cost } \\
=3,24,000 / \text { season) }\end{array}$ & $\begin{array}{l}\text { Rs.51,14,880/season } \\
\text { Rs. } 244 / \text { bale } \\
\text { (Power } \\
\text { cost }=19,82,880 / \text { season } \\
\text { And Labor cost } \\
=31,32,000 / \text { season) }\end{array}$ & $\begin{array}{l}\text { Rs } 11,23,200 / \text { Seas } \\
\text { on of } 4 \text { months. } \\
\text { i.e.Rs } 69.5 / \text { bale }\end{array}$ \\
\hline \multicolumn{2}{|c|}{$\begin{array}{l}\text { Total production } \\
\text { For } 4 \text { month season }\end{array}$} & $\begin{array}{l}324 \\
\text { qtl/dayx } 120 \text { working } \\
\text { days = } 38,880 \mathrm{qtl} \\
\text { /season } \\
=22,870 \text { bales } / \text { season } \\
\text { (One bale }=170 \mathrm{~kg} \\
\text { Average wt.) }\end{array}$ & $\begin{array}{l}297 \mathrm{qtl} / \text { dayx } 120 \\
\text { working } \\
\text { days }=35,640 \mathrm{qtl} / \mathrm{seas} \text { on } \\
=20,964 \mathrm{bales} / \mathrm{season}\end{array}$ & $\begin{array}{l}1859 \text { bales extra } \\
\text { production by } \\
\text { Modernized } \\
\text { automated unit. }\end{array}$ \\
\hline
\end{tabular}

\section{OTHER BENEFITS-}

1- Safe working.

2- Optimum Moisture content.

3- Ginned Cotton good quality free from impurities and trash.

4- Get $10 \%$ extra rate for job work of ginning and pressing.

\subsection{CONCLUSION}

Modernized automated ginning and pressing unit not only gives quality output at $40 \%$ less operational cost but also fetches $10 \%$ extra amount in job work of ginning and pressing for other parties. In India majority of ginning and pressing units are involved in doing job work of Cotton Corporation of India and get higher rate for modernized set up. There are also other benefits like export grade output, increase production by $8 \%-9 \%$ and get good price to cotton in market, etc.

\section{REFERENCES}

a) HMT Ltd. 'Mechatronics', Tata McGraw Hill publishing company ltd, pp.315-322.

b) Peter Rohner \& Gorden Smith 1987,'Pneumatic control for Industria Automation John Willy and Sons: pp.36-58,158-192.

c) Harry L Stewart, 1987, 'Pneumatics \& Hydraulics ', pp.374-376

d) Peter Rohner, 1979, 'Fluid Power Logic Control', The Macmillan Press ltd. 
e) Mickell P. Groover, 1999 'Automation, Production systems, and computer Integrated Manufacturing' Prentice - Hall of India Pvt. Ltd., pp.673-705.

f) Project Directors report, 2007, 'Annual Report 06-07', Directorate of seed Research pp.547-550.

g) Press Release, 2007, 'Brief heights of CCI'S Performance', Cotton Corporation of India, pp.1-3. (http://www.cotcorp.gov.in/press/AGM\%20press\%20release.pdf)

h) Sandeep Bajoria, 2007, 'Emerging trends in cotton seed production and utilization in India', pp.2, 3.

i) Murali Siddaiah, Michael A. Lieberman, Nadipuram S. Prasad, S. E Hughs, 2004 'Automation in cotton ginning' http://wotan.liu.edu/docis/dbl/ijinsy/2004_19_1_2_111_AICG.html 